\title{
ANALISIS KERUSAKAN JALAN DENGAN MENGGUNAKAN METODE PCI DAN STRATEGI PENANGANANNYA (STUDI KASUS JALAN NASIONAL SRIJAYA RAYA PALEMBANG KM 8+149 SD KM9+149)
}

\author{
Delli Noviarti Rachman, Putri Indah Sari \\ Teknik Sipil Universitas Tamansiswa Palembang \\ Jalan Tamansiswa No. 261.Palembang kode pos 30126 \\ E-mail : delli_noviarti @unitaspalembang.ac.id
}

\begin{abstract}
Abstrak
Jalan Srijaya Raya merupakan jalan Nasional yang sangat rentan akan kerusakan. Hal ini terjadi karena semua jenis kendaraan melewati jalan tersebut tanpa batasan tonase. Agar selalu lancar, maka jalan nasional sangat membutuhkan pemeliharaan dan perbaikan yang berkala. Perbaikan dilakukan sesuai dengan hasil survey kerusakan.

Salah satu penilaian jalan adalah dengan menggunakan system PCI, dimana kerusakan ruas jalan akan diukur secara manual dan dengan menggunakan standar yang akan dilakukan penilaian.

Hasil dari survey dan pengukuran PCI ini terdapat 4 jenis kerusakan yang terjadi pada ruas jalan Srijaya Raya KM 8+149 sampai dengan KM 9+149, yaitu pelepasan butir, devormasi / penurunan, bleeding atau kegemukan, lubang, dan retak buaya. Secara umum nilai PCI untuk jalan Srijaya Raya pada KM 8+149 sampai dengan KM 9+149 adalah 61, yang artinya kondisi jalan dalam keadaan baik. Total biaya pemeliharaan terhadap kerusakan yang diderita oleh jalan Srijaya Raya pada KM 8+149 sampai dengan KM 9+149 adalah Rp. 86.212.428,- atau dibulatkan Rp. 86.213.000,-.
\end{abstract}

Kata Kunci : PCI, Kerusakan Jalan, Perawatan Jalan,

\section{Pendahuluan}

Jalan adalah suatu prasarana perhubungan darat dalam bentuk apapun meliputi segala bagian jalan termasuk bangunan pelengkap dan perlengkapannya yang diperuntukkan bagi lalu lintas (UU Jalan No.13/1980). Jalan merupakan prasarana penting dalam transportasi yang dapat berpengaruh terhadap kemajuan bidang ekonomi, sosial, budaya maupun politik di suatu wilayah.

Untuk kenyamanan dan keamanan bagi pengemudi, jalan harus didukung oleh perkerasan yang baik. Perkerasan jalan adalah campuran antara agregat dan bahan ikat yang digunakan untuk melayani beban lalu lintas. Perkerasan jalan dibagi atas dua kategori yaitu perkerasan lentur (flexible pavement) dan perkerasan kaku (rigid pavement). Perkerasan lentur adalah perkerasan yang menggunakan aspal sebagai bahan pengikat sedangkan perkerasan kaku adalah jenis perkerasan jalan yang menggunakan beton sebagai bahan utama perkerasan tersebut.

Lapisan perkerasan jalan terdiri dari lapis permukaan (surface course), lapis pondasi atas (base course), lapis pondasi bawah (subbase course) dan tanah dasar (subgrade). Lapisanlapisan tersebut berfungsi untuk menerima dan menyebarkan beban lalu lintas tanpa menimbulkan kerusakan yang berarti pada konstruksi jalan itu sendiri. Dengan demikian memberikan kenyamanan kepada pengemudi selama masa pelayanan jalan tersebut.

Jalan Srijaya Raya Palembang merupakan jalan nasional dengan fungsi sebagai jalan arteri primer. Sebelum dilakukan pelebaran, jalan ini memiliki lebar perkerasan $2 \times 3,5 \mathrm{~m}$ dengan tipe perkerasan aspal laston dan tipe jalan masih 2 lajur 2 arah tanpa median (2/2 UD). Namun setelah dilaksanakan pelebaran, sekarang jalan Srijaya Raya telah memiliki lebar $2 \times 7 \mathrm{~m}$ dengan median.

Jalan Srijaya Raya dimulai dari KM KM 08+149 sampai dengan KM 14+449 atau sepanjang lebih kurang $6 \mathrm{KM}$, sebelum masuk ke jalan Palembang - Indralaya.

Namun umur jalan yang sudah direncanakan pada kenyataannya tidak sesuai dengan yang terjadi di lapangan. Seringkali kondisi jalan 
sudah mengalami kerusakan sebelum masa layan jalan tersebut habis. Hal tersebut dapat dipengaruhi oleh beberapa faktor di antaranya pertumbuhan lalu lintas yang tidak sesuai prediksi, beban lalu lintas yang melampaui batas (overloading), kondisi tanah dasar yang buruk, tidak sesuainya material yang digunakan, faktor lingkungan serta pelaksanaan yang tidak sesuai dengan perencanaan. Terdapat berbagai jenis kerusakan yang dapat terjadi pada perkerasan lentur, oleh sebab itu dibutuhkan penelitian untuk mengetahui kondisi permukaan jalan dengan melakukan pengamatan secara visual.

Berdasarkan latar belakang di atas, penelitian ini dilakukan untuk mengidentifikasi jenis kerusakan dan mengetahui nilai PCI agar didapatkan prioritas penanganannya.

\section{A. Tujuan Penelitian}

Tujuan dari penelitian ini adalah

1. Untuk mengetahui jenis-jenis kerusakan yang terjadi pada perkerasan lentur (flexible pavement) pada ruas jalan Sri Jaya Raya Palembang.

2. Mengetahui nilai indeks kerusakan dengan metode Pavement Condition Index (PCI) pada perkerasan lentur (flexible pavement).

3. Mengetahui berapa biaya pemeliharaan jalan Srijaya Raya pada KM 8+149 sampai dengan KM 9+149 (di pangkal jalan)

\section{B. Kajian Literatur}

\section{Jenis Kerusakan Lentur Jalan}

Khusus untuk keperluan dalam perhitungan nilai kondisi jalan menggunakan metode Pavement Condition Index (PCI), jenis-jenis kerusakan pada perkerasan lentur diklasifikasikan sebagai berikut :

\section{Retak kulit buaya (alligator cracking)}

Retak kulit buaya adalah serangkaian retak memanjang paralel yang membentuk banyak sisi menyerupai kulit buaya.

\section{Kegemukan (bleeding)}

Kegemukan adalah hasil dari aspal pengikat yang berlebihan, yang bermigrasi ke atas permukaan perkerasan. Kelebihan kadar aspal atau terlalu rendahnya kadar udara dalam campuran, dapat mengakibatkan kegemukan.

3. Retak blok (block cracking)

Retak blok ini berbentuk blok-blok besar yang saling bersambungan, dengan ukuran sisi blok 0,3 sampai $3 \mathrm{~m}$ dan dapat membentuk sudut atau pojok yang tajam.

\section{Tonjolan dan lengkungan (bump and sags)}

Tonjolan adalah gerakan atau perpindahan ke atas, bersifat lokal dan kecil dari permukaan perkerasan aspal.

\section{Keriting (corrugation)}

Keriting atau bergelombang adalah kerusakan akibat terjadinya deformasi plastis yang menghasilkan gelombang-gelombang melintang atau tegak lurus arah perkerasan.

\section{Amblas (depressions)}

Amblas adalah penurunan perkerasan yang terjadi pada area terbatas yang mungkin dapat diikuti dengan retakan.

\section{Retak tepi (edge cracking)}

Retak tepi biasanya terjadi sejajar dengan tepi perkerasan dan berjarak sekitar 0,3-0,5 $\mathrm{m}$ dari tepi luar.

8. Retak refleksi sambungan (joint reflection cracking)

Kerusakan ini umumnya terjadi pada permukaan perkerasan aspal yang telah dihamparkan di atas perkerasan beton.

9. Penurunan bahu jalan (lane/shoulder drop off) adalah adalah beda elevasi antara tepi perkerasan dan bahu jalan.

10. Retak memanjang / melintang (longitudinal /transverse cracking) adalah retak berbentuk memanjang pada perkerasan jalan, dapat terjadi dalam bentuk tunggal atau berderet yang sejajar dan kadang-kadang sedikit bercabang. Retak melintang merupakan retak tunggal (tidakbersambungan satu sama lain) yang melintang perkerasan.

11. Tambalan dan galian utilitas (patching and utility cut patching)

Tambalan adalah penutupan bagian perkerasan yang mengalami perbaikan. 


\section{Pengausan (polished aggregate)}

Pengausan adalah licinnya bagian perkerasan, akibat ausnya agregat di permukaan.

\section{Lubang (potholes)}

Lubang adalah lekukan permukaan perkerasan akibat hilangnya lapisan aus dan material lapis pondasi. Kerusakan berbentuk lubang kecil biasanya berdiameter kurang dari $0,9 \mathrm{~m}$ dan berbentuk mangkuk yang dapat berhubungan atau tidak berhubungan dengan permukaan lainnya. Lubang biasanya terjadi akibat galian utilitas atau tambalan di area perkerasan yang telah ada.

\section{Persilangan jalan rel (railroad crossing)}

Kerusakan pada persilangan jalan rel dapat berupa amblas atau tonjolan di sekitar dan atau antara lintasan rel.

\section{Alur (rutting)}

Alur adalah deformasi permukaan perkerasan aspal dalam bentuk turunnya perkerasan ke arah memanjang pada lintasan roda kendaraan.

\section{Sungkur (shoving)}

Sungkur adalah perpindahan permanen secara lokal dan memanjang dari permukaan perkerasan yang disebabkan oleh beban lalu lintas.

\section{Retak selip (slippage cracking)}

Retak selip atau retak yang berbentuk bulan sabit yang diakibatkan oleh gaya-gaya horizontal yang berasal dari kendaraan.

\section{Pengembangan (swell)}

Pengembangan adalah gerakan lokal ke atas dari perkerasan akibat pengembangan (pembekuan air) dari tanah dasar atau dari bagian struktur perkerasan.

19. Pelapukan dan pelepasan butir (weathering and raveling)

Pelapukan dan pelepasan butir adalah disintegrasi permukaan perkerasan aspal melalui pelepasan partikel agregat yang berkelanjutan, berawal dari permukaan perkerasan menuju ke bawah atau dari tepi ke dalam.

\section{Pavement Condition Index (PCI)}

Metode survei dari PCI mengacu pada ASTM D6433 (Standard Practice for Roads and Parking Lots Pavement Condition Surveys).
Pavement Condition Index (PCI) adalah sistem penilaian kondisi perkerasan jalan berdasarkan jenis, tingkat dan luas kerusakan yang terjadi dan dapat digunakan sebagai acuan dalam usaha pemeliharaan. Nilai PCI ini memiliki rentang 0 sampai 100 dengan kriteria sempurna (excellent), sangat baik (very good), baik (good), sedang (fair), jelek (poor), sangat jelek (very poor) dan gagal (failed).

\section{a. Tingkat kerusakan (Severity level)}

Severity level adalah tingkat kerusakan pada tiaptiap jenis kerusakan. Tingkat kerusakan yang digunakan dalam perhitungan PCI adalah low severity level $(\mathrm{L})$, medium severity level $(\mathrm{M})$ dan high severity level $(\mathrm{H})$.

Untuk jenis kerusakan pengausan (polished aggregate), tidak ada definisi derajat kerusakan. Tetapi derajat kelicinan harus tampak signifikan sebelum dinilai sebagai kerusakan.

\section{b. Density (kadar kerusakan)}

Density atau kadar kerusakan adalah persentase luasan dari suatu jenis kerusakan terhadap luasan suatu unit segmen yang diukur dalam meter persegi atau meter panjang. Nilai density suatu jenis kerusakan dibedakan juga berdasarkan tingkat kerusakannya. Rumus mencari nilai density :

$$
\begin{gathered}
\text { Density = Ad/As x } 100 \% \text { atau } \\
\text { Density }=\mathrm{Ld} / \mathrm{As} \times 100 \% \ldots \ldots \ldots \ldots \ldots \ldots \text { (pers. } 1)
\end{gathered}
$$

Untuk jenis kerusakan lubang, density dihitung dengan rumus :

$$
\text { Density }=\mathrm{n} / \text { As } \times 100 \%
$$

dengan :

Ad: luas total jenis kerusakan unntuk tiap tingkat kerusakan $\left(\mathrm{m}^{2}\right)$

As: luas total unit segmen $\left(\mathrm{m}^{2}\right)$

Ld: panjang total jenis kerusakan untuk tiap tingkat kerusakan (m)

$\mathrm{N}$ : jumlah lubang untuk tiap tingkat kerusakan

\section{c. Deduct value (nilai pengurangan)}

Deduct value adalah nilai pengurangan untuk tiap jenis kerusakan yang diperoleh dari kurva hubungan antara density dan deduct value. Deduct value juga dibedakan atas tingkat kerusakan untuk tiap-tiap jenis kerusakan. 
d. Total deduct value (TDV)

Total deduct value adalah nilai total dari individual deduct value untuk tiap jenis kerusakan dan tingkat kerusakan yang ada pada suatu unit penelitian.

e. Nilai allowable maximum deduct value $(\mathrm{m})$

Sebelum ditentukan nilai TDV dan CDV nilai deduct value perlu di cek apakah nilai deduct value individual dapat digunakan dalam perhitungan selanjutnya atau tidak dengan melakukan perhitungan nilai alowable maximum deduct value $(\mathrm{m})$.

$m=1+9 / 98(100-$ HDVi $)$ (Pers. 3) dengan :

m: nilai koreksi untuk deduct value

HDVi : nilai terbesar deduct value dalam satu sampel unit

\section{f. Corrected deduct value (CDV)}

Corrected deduct value (CDV) diperoleh dari kurva hubungan antara nilai TDV dengan nilai CDV dengan pemilihan lengkung kurva sesuai dengan jumlah nilai individual deduct value yang mempunyai nilai lebih besar dari 2 (dua) yang disebut juga dengan nilai (q).

Menurut (Shahin, 1994) sebelum ditentukan nilai CDV harus ditentukan terlebih dahulu nilai CDV maksimum yang telah terkoreksi dapat diperoleh dari hasil pendekatan deduct value dari yang terkecil nilainya dijadikan $=2$ sehingga nilai $\mathrm{q}$ akan berkurang sampai diperoleh nilai $\mathrm{q}=1$ setelah itu nilai deduct value di totalkan (TDV) kemudian hubungkan TDV dengan nilai q.

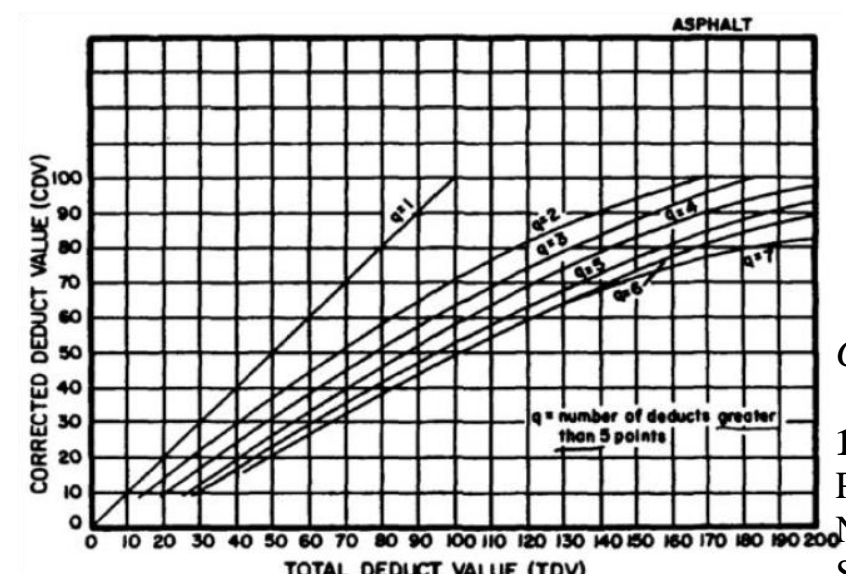

Gambar 1. Grafk Hubungan CDV dan TDV untuk perkerasan lentur

Jika nilai CDV telah diketahui, maka nilai PCI untuk tiap unit dapat diketahui dengan rumus :
$\operatorname{PCI}(\mathrm{s})=100-\mathrm{CDV}$ .(Pers 4)

dengan :

PCI(s) : nilai PCI untuk tiap unit

CDV: nilai CDV untuk tiap unit

Untuk Nilai PCI secara keseluruhan :

$$
P C I=\frac{\sum P C I(s)}{N} \ldots \ldots \ldots \ldots \ldots(\text { Pers. 5) }
$$

dengan :

PCI: nilai PCI perkerasan keseluruhan

PCI(s): nilai PCI untuk tiap unit

$\mathrm{N}$ : jumlah unit

Dari nilai PCI untuk masing-masing unit penelitian dapat diketahui kualitas lapis perkerasan unit segmen berdasarkan kondisi tertentu yaitu sempurna (excellent), sangat baik (very good), baik (good), sedang (fair), jelek (poor), sangat jelek (very poor) dan gagal (failed).

$$
\text { PCI }
$$

Rating

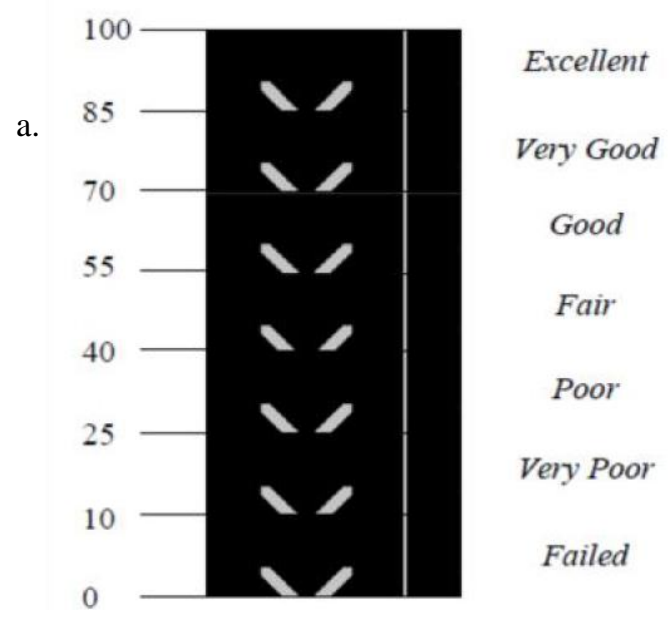

Gambar 2. Ratting kondisi jalan berdasarkan metode PCI

\section{Metodologi Penelitian}

\section{Lokasi dan Waktu Penelitian}

Penelitian ini hanya dilakukan pada ruas Jalan Nasional Srijaya Raya (Sta. 0.000 dimulai Simpang 4 Lingkar Selatan yaitu KM 8+149 sampai Sta. 1.000 di batas Kota Palembang KM 9+149). Penulis hanya mengambil sampel sepanjang $1 \mathrm{KM}$ dari total 6,3 KM panjang jalan Srijaya Raya. Sedangkan waktu penelitian ini 
dilakukan pada bulan Januari - Mei 2019.

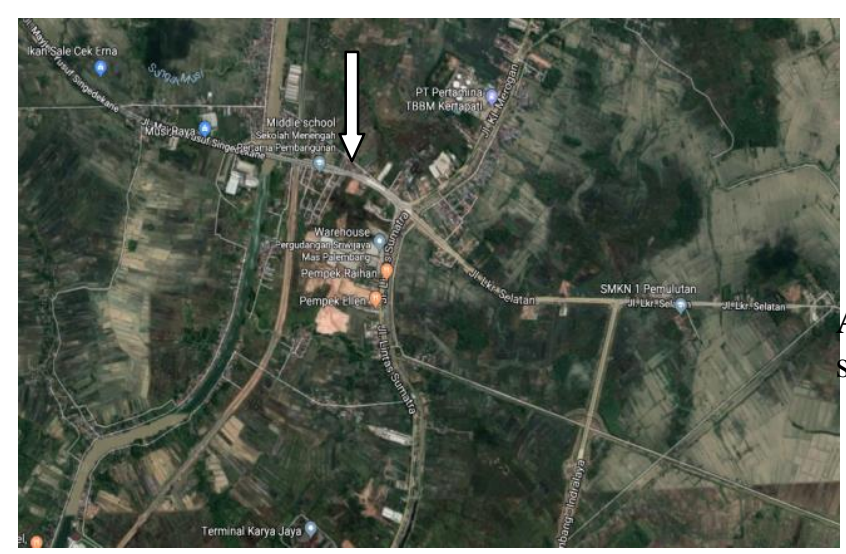

Gambar 3. Peta Lokasi Peneltian

\section{Teknik Pengumpulan Data}

\section{a. Teknik Observasi}

Teknik observasi yaitu teknik pengumpulan data dengan cara melakukan survei pendahuluan dan juga pengambilan data langsung ke lokasi di antaranya survei visual tipe - tipe kerusakan jalan yang terjadi pada ruas Jalan Srijaya Raya Palembang.

Survey pendahuluan merupakan survey yang harus dilakukan pada awal kegiatan, yakni sebelum survey detail karena survey detail akan mengacu pada hasil survey ini. Survey ini bertujuan untuk mengetahui kondisi umum perkerasan, dan jenis - jenis kerusakan yang sering terjadi dilapangan. Hal ini akan sangat membantu untuk survey selanjutnya karena sudah memiliki gambaran kondisi lapangan.

\section{b.Teknik dokumentasi}

Teknik dokumentasi yaitu teknik pengumpulan data dengan cara mengambil gambar dan foto kerusakan jalan

\section{Alat Penelitian}

Alat yang digunakan dalam teknik survei adalah sebagai berikut:
a) Pengukur keretakan
b) Formulir yang digunakan terdiri dari formulir survei kondisi jalan beraspal di perkotaan (SKJ - 1).
c) Penggaris
d) Roll meter
e) Kamera digital

\section{Langkah Pelaksanaan Survey}

Pengumpulan data dilakukan dengan cara survei visual dan dibagi menjadi dua tahap yaitu :
- Tahap 1 : Survei pendahuluan, yaitu untuk mengetahui lokasi dan panjang tiap segmen perkerasan lentur.

- Tahap 2 : Survei kerusakan, yaitu untuk mengetahui jenis-jenis kerusakan, dimensi kerusakan dan mendokumentasikan segala jenis kerusakan pada masing-masing unit sampel.

Adapun langkah-langkah untuk pelaksanaan survei kerusakan adalah sebagai berikut :

a. Membagi tiap segmen menjadi beberapa unit sampel, pada penelitian ini unit sampel dibagi setiap jarak 50-100 meter.

b. Mendokumentasikan tiap kerusakan yang ada.

c. Menentukan tingkat kerusakan (severity level).

d. Mengukur dimensi kerusakan pada tiap unit sampel.

e. Mencatat hasil pengukuran ke dalam form survei.

\section{Analisis Hasil Survey}

Analisis kondisi jalan menggunakan metode Pavement Condition Index (PCI)

a. Menghitung density (kadar kerusakan).

b. Menentukan nilai deduct value tiap jenis kerusakan.

c. Menghitung alowable maximum deduct value (m).

d. Menghitung nilai total deduct value (TDV).

e. Menentukan nilai corrected deduct value (CDV).

f. Menghitung nilai PCI (Pavement Condition Index)

\section{Diagram Alir Penelitian}

Penelitian dilaksanakan dengan prosedur yang sistematik dengan tahapan-tahapan yang dapat terlihat pada Gambar 4. 


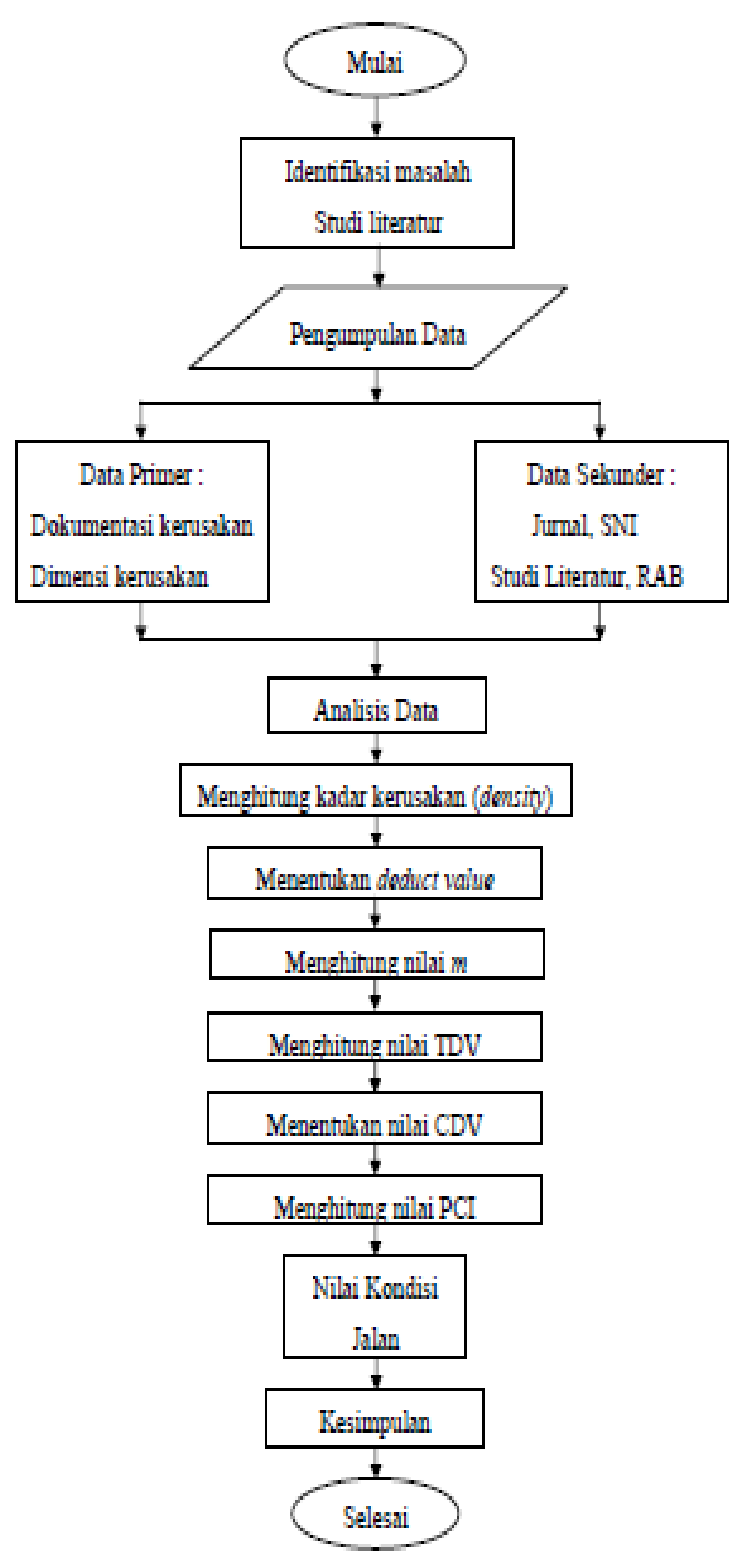

sebagai titik 1+000R untuk sebelah kanan, serta $1+000 \mathrm{~L}$ untuk sebelah kiri.

Jalan Srijaya Raya memiliki lebar perkerasan $2 \mathrm{x}$ $7 \mathrm{~m}$ yang terdiri dari 4 lajur 2 arah dengan lebar median $1 \mathrm{~m}(4 / 2 \mathrm{D})$. Lebar bahu jalan sebesar 2 $m$ dengan kondisi tanpa perkerasan. Saluran samping jalan memiliki kedalaman 1,4 m dengan lebar saluran bagian atas $1,3 \mathrm{~m}$ dan bagian bawah $0,8 \mathrm{~m}$. Jalan Srijaya Raya ini terdiri dari perkerasan lentur (flexible pavement) dan perkerasan kaku (rigid pavement).

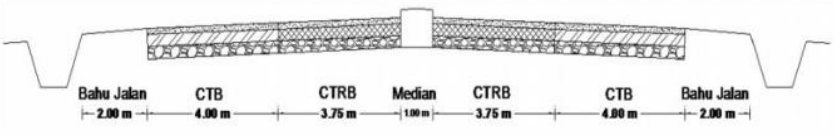

Gambar 5. Potongan melintang jalan

\begin{abstract}
A. Hasil Survey
Pengukuran untuk setiap jenis kerusakan dilakukan pada jalan Srijaya Raya Palembang sepanjang 1,0 KM. Data yang diperoleh dimasukan kedalam formulir yang tersedia. Survey dilaksanakan pada sisi kiri dan kanan badan jalan.
\end{abstract}

Tabel 1. Hasil Survey Kerusakan Ruas Jalan Srijaya Raya Kanan STA 00+000R s/d 01+000R (Kanan)

Gambar 4. Diagram Alir Peneltian

\title{
2. Hasil dan Pembahasan
}

Telah dibahas sebelumnya bahwa penelitian ini dilaksanakan di lokasi Jalan Srijaya Raya Palembang yaitu dimulai pada Simpang 4 Lingkar Selatan (KM 8+149) sampai batas kota Palembang di KM 14+449 yang lebih kurang 6,3 KM. Lokasi lebih detailnya dapat dilihat pada peta lokasi di bawah ini. Namun dalam penelitian ini hanya diambil sampel sepanjang $1 \mathrm{KM}$, yaitu pada KM 8+149 - KM 9+149. Titik awal di KM $8+149$ akan dianggap sebagai titik 0+000R untuk sebelah kanan dan 0+000L untuk sebelah kiri dan titik akhir di KM 9+149 akan dianggap 


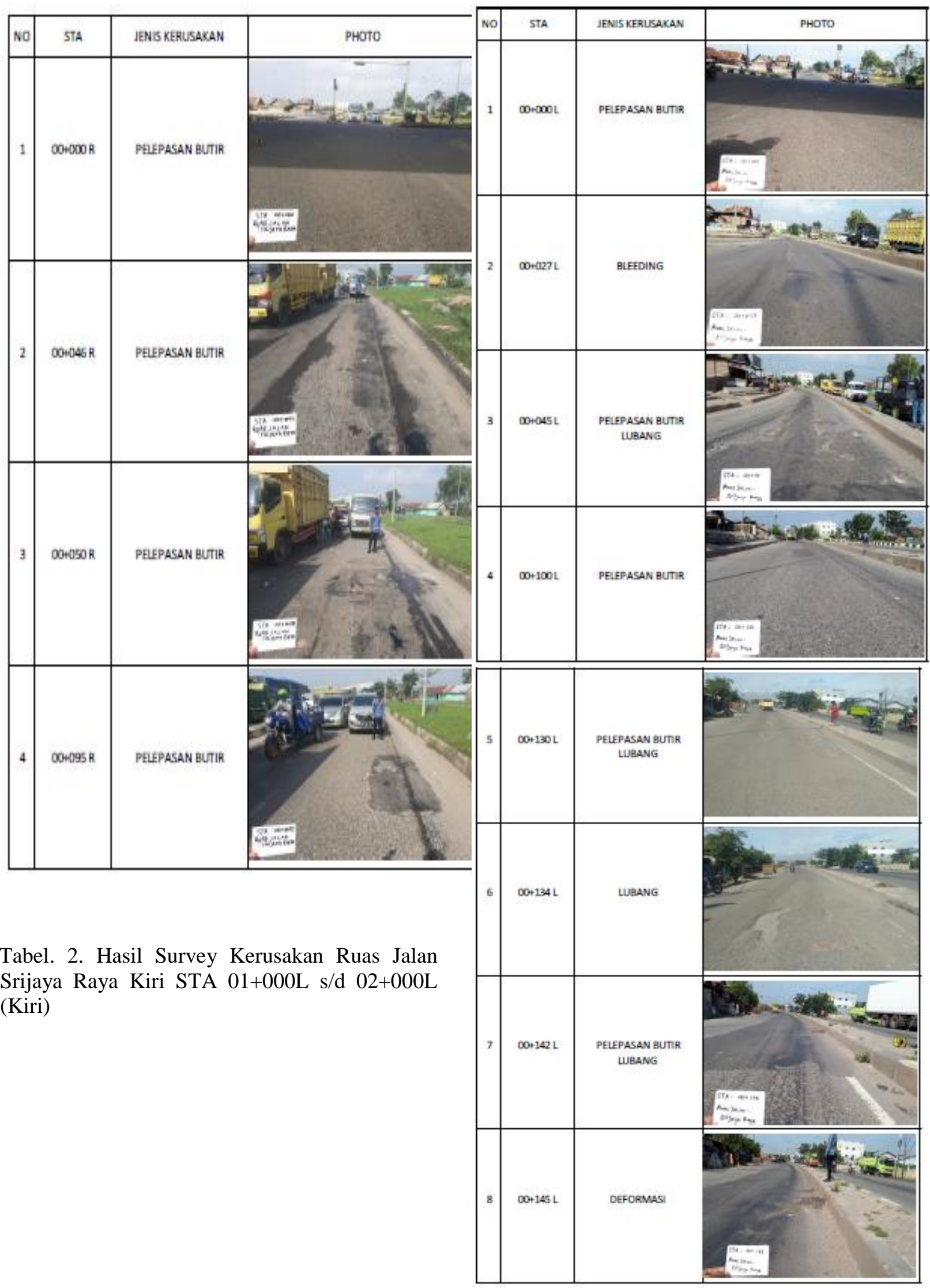



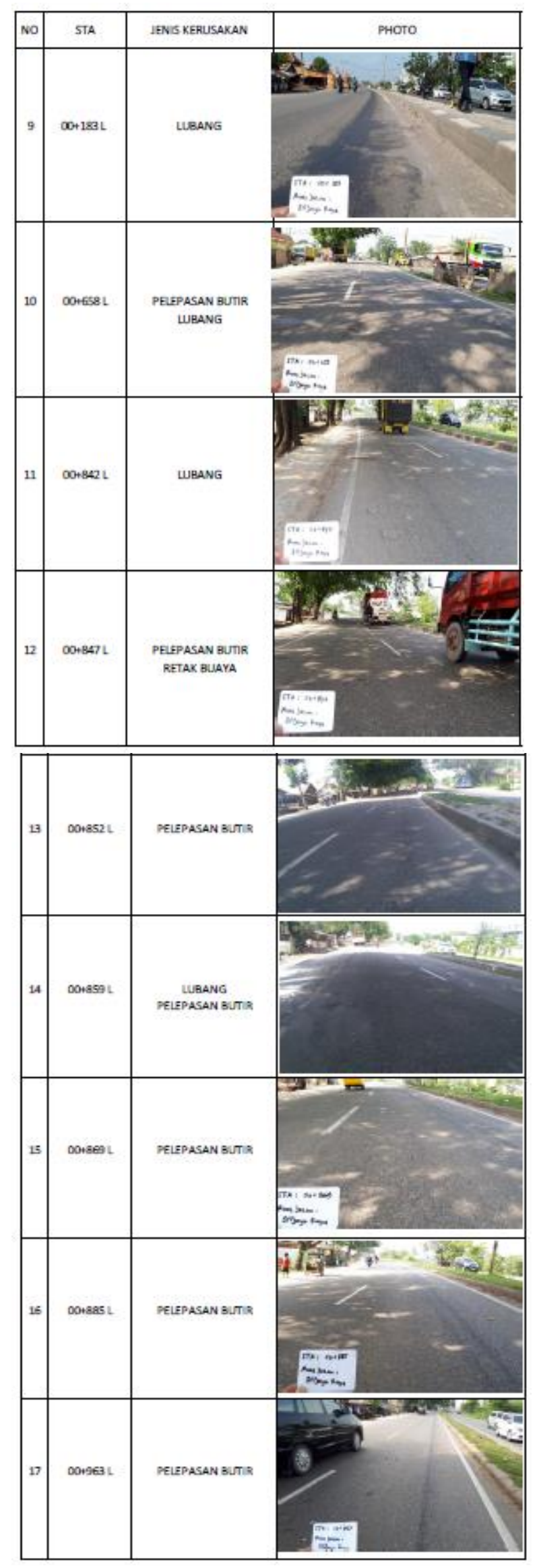

Berdasarkan hasil survey di lapangan, maka didapatkan data-data kerusakan sebagai berikut :

Tabel 3. Hasil Survey Jenis Kerusakan Jalan Srijaya Raya Palembang sepanjang $1 \mathrm{KM}$

\begin{tabular}{|c|c|c|c|c|}
\hline STA & Jenis Kerusakan & Luasan & $\begin{array}{c}\text { Kelas } \\
\text { Kerusakan }\end{array}$ & $\begin{array}{c}\text { Leasan } \\
\text { (m2) }\end{array}$ \\
\hline \multicolumn{5}{|c|}{ Sisi Kanan } \\
\hline $00+000 \mathrm{R}$ & Polopasan Betir & $6 \mathrm{~m} \times 10 \mathrm{~m}$ & $\mathrm{M}$ & 60 \\
\hline $00 \div 046 \mathrm{R}$ & Polopasan Betir & $5 \mathrm{mx} 2 \mathrm{~m}$ & $\mathrm{~L}$ & 10 \\
\hline $00+050 \mathrm{R}$ & Polepasan Betir & $3 \mathrm{mx} 1 \mathrm{~m}$ & $\mathrm{~L}$ & 3 \\
\hline $00+095 \mathrm{R}$ & Polepasan Butir & $2 \mathrm{~m} \times 1 \mathrm{~m}$ & $\mathrm{M}$ & 2 \\
\hline \multicolumn{5}{|c|}{ Sixi Kiri } \\
\hline $00+000 \mathrm{~L}$ & Polepasan Betir & $6 \mathrm{~m} \times 10 \mathrm{~m}$ & $\mathrm{M}$ & 60 \\
\hline $00+027 \mathrm{~L}$ & Bloqding & $2 m \times 5 m$ & $\mathrm{~L}$ & 10 \\
\hline \multirow[t]{2}{*}{$00+045 \mathrm{~L}$} & Polopasan Butir & $2 m \times 5 m$ & L & 10 \\
\hline & Lubang & $2 m \times 5 m$ & $\mathrm{~L}$ & 10 \\
\hline $00+100 \mathrm{~L}$ & Polopasan Butir & $6 \mathrm{~m} \times 10 \mathrm{~m}$ & M & 60 \\
\hline \multirow[t]{2}{*}{$00+130 \mathrm{~L}$} & Polepasan Betir & $6 \mathrm{~m} \times 10 \mathrm{~m}$ & $\mathrm{M}$ & 60 \\
\hline & Lubang & $2 m \times 3 m$ & $\mathrm{M}$ & 18 \\
\hline $00+134 \mathrm{~L}$ & Lubang & $1 \mathrm{mx} 2 \mathrm{~m}$ & $\mathrm{~L}$ & 4 \\
\hline \multirow[t]{2}{*}{$00+142 \mathrm{~L}$} & Polepasan Butir & $2 \mathrm{~m} \times 5 \mathrm{~m}$ & $\mathrm{~L}$ & 3 \\
\hline & Lubang & $1 \mathrm{mx} 2 \mathrm{~m}$ & $\mathrm{~L}$ & 2 \\
\hline $00+145 \mathrm{~L}$ & Doformasi & $1 \operatorname{mx} 10 \mathrm{~m}$ & $\mathrm{M}$ & 10 \\
\hline $00+183 \mathrm{~L}$ & Lubang & $1 \mathrm{mx} 2 \mathrm{~m}$ & $\mathrm{M}$ & 2 \\
\hline \multirow[t]{2}{*}{$00+658 \mathrm{~L}$} & Polepasan Brtir & $2 m \times 5 m$ & M & 10 \\
\hline & Lubang & $1 \mathrm{mx} 2 \mathrm{~m}$ & $\mathrm{~L}$ & 2 \\
\hline $00+842 \mathrm{~L}$ & Lubang & $1 \mathrm{mx} 1 \mathrm{~m}$ & $\mathrm{~L}$ & 1 \\
\hline \multirow[t]{2}{*}{$00+847 \mathrm{~L}$} & Polopasan Betir & $4 \mathrm{mx} 6 \mathrm{~m}$ & $\mathrm{M}$ & 24 \\
\hline & Retak Bmaya & $4 m \times 6 m$ & L & 24 \\
\hline $00+852 \mathrm{~L}$ & Polopasan Brtir & $4 \mathrm{mx} 6 \mathrm{~m}$ & $\mathrm{M}$ & 24 \\
\hline \multirow[t]{2}{*}{$00+859 \mathrm{~L}$} & Lubang & $1 \mathrm{mx} 2 \mathrm{~m}$ & $\mathrm{M}$ & 2 \\
\hline & Polopasan Betir & $4 \mathrm{mx} 6 \mathrm{~m}$ & $\mathrm{M}$ & 24 \\
\hline $00+869 \mathrm{~L}$ & Polopasan Butir & $4 m \times 6 m$ & L & 24 \\
\hline $00+885 \mathrm{~L}$ & Polopasan Butir & $4 m \times 6 m$ & $\mathrm{~L}$ & 24 \\
\hline $00+963 \mathrm{~L}$ & Poleparan Butir & $4 \mathrm{~m} \times 6 \mathrm{~m}$ & L & 24 \\
\hline
\end{tabular}

\section{B. Menghitung Nilai PCI}

Adapun langkah - langkah pengukuran setiap jenis kerusakannya adalah sebagai berikut
a) Menghitung density (kadar kerusakan).
b) Menentukan nilai deduct value tiap jenis kerusakan.
c) Menghitung alowable maximum deduct value $(\mathrm{m})$.
d) Menghitung nilai total deduct value (TDV).
e) Menentukan nilai corrected deduct value (CDV).
f) Menghitung nilai PCI (Pavement Condition Index)

\section{a. Pengukuran density (kadar kerusakan) setiap kerusakan}

Perhitungan nilai densitas merupakan tahapan awal yang dilakukan dalam perhitungan Pavement Condition Index (PCI) yang didasarkan pada data hasil peninjauan untuk setiap jenis kerusakan.

Densitas atau kadar kerusakan didapat dari luas kerusakan dibagi dengan luas pekerjaan jalan (tiap segmen) kemudian dikali $100 \%$. Nilai 
density diperoleh dari pers 1 untuk suatu jenis kerusakan yang dibedakan menurut tingkat kerusakannya.

Contoh perhitungan pada ruas $00-000 \mathrm{R}-01.000 \mathrm{R}$ $\mathrm{m}$ :

Rumus yang digunakan : Density $=\operatorname{Ad} / \mathrm{As} \mathrm{x}$ $100 \%$

Nilai Ad = luas total jenis kerusakan unntuk tiap tingkat kerusakan $\left(\mathrm{m}^{2}\right)=62 \mathrm{~m} 2$

Nilai As $=$ luas total unit segmen $\left(\mathrm{m}^{2}\right)=1000 \mathrm{~m}$ $\mathrm{x} 7 \mathrm{~m}=7.000 \mathrm{~m} 2$

Density $=\mathrm{Ad} /$ As $\times 100 \%$

$$
=62 / 7.000 \times 100 \%=0,886 \%
$$

Berikut ditampilkan persentase hasil survey kerusakan yang terjadi pada segmen ruas jalan Srijaya Raya Palembang

Tabel 4. Perhitungan Density Kerusakan

\begin{tabular}{|c|c|c|c|c|}
\hline STA & Jenis Kerusakan & $\begin{array}{c}\text { Kelas } \\
\text { Kerusakan }\end{array}$ & $\begin{array}{c}\text { Leasan } \\
(\mathrm{m} 2)\end{array}$ & $\begin{array}{c}\text { Density } \\
\text { Kerusalkan } \\
\text { (\%) }\end{array}$ \\
\hline \multicolumn{5}{|c|}{ Sixi Kanan } \\
\hline \multirow{2}{*}{$\begin{array}{l}00+0.000 R \text { - } \\
00+1.000 R\end{array}$} & Polepanm Butir & $\mathrm{M}$ & 62 & 0,886 \\
\hline & Polepasum Butir & L & 13 & 0,186 \\
\hline \multicolumn{5}{|c|}{ Sisi Kiri } \\
\hline \multirow{7}{*}{$\begin{array}{l}00+0.000 \mathrm{~L}- \\
00+1.000 \mathrm{~L}\end{array}$} & Polepsum Butir & $\mathrm{M}$ & 262 & 3,7429 \\
\hline & Polepanm Butir & L & 87 & 1,2429 \\
\hline & Blooding & $\mathrm{M}$ & 10 & 0,1429 \\
\hline & Deformani & $\mathrm{M}$ & 10 & 0,1429 \\
\hline & Lubang & $\mathrm{M}$ & 20 & 0,2857 \\
\hline & Lubang & $\mathrm{L}$ & 19 & 0,2714 \\
\hline & Rotnk Buxy & L & 24 & 0.3429 \\
\hline
\end{tabular}

\section{b. Pengukuran Deduct Value (DV)}

Deduct Value (nilai pengurangan) adalah suatu nilai pengurang untuk setiap jenis kerusakan yang diperoleh dari kurva hubungan kerapatan (density) dan tingkat keparahan (severity level) kerusakan, sebagai contoh grafik menurut jenis kerusakan.

\section{c. Pengukuran Total Deduct Value (TDV)}

Total deduct value adalah nilai total dari individual deduct value untuk tiap jenis kerusakan dan tingkat kerusakan yang ada pada suatu unit penelitian.

\section{Tabel 5. Total Deduct Value}

\begin{tabular}{|c|c|c|c|c|}
\hline STA & Jenis Kerusaban & $\begin{array}{c}\text { Kelas } \\
\text { Kerusalean }\end{array}$ & $\begin{array}{c}\text { Deusity } \\
\text { Kerualkam } \\
(\% 6)\end{array}$ & $\begin{array}{l}\text { Deduct } \\
\text { Valoe }\end{array}$ \\
\hline \multicolumn{5}{|c|}{ Seri Kanan } \\
\hline \multirow{2}{*}{$\begin{array}{l}00+0.000 \mathrm{R}- \\
00+1.000 \mathrm{R}\end{array}$} & Polepasn Butir & M & 0,886 & 9 \\
\hline & Polepasan Butir & L & 0,186 & 0 \\
\hline \multicolumn{5}{|c|}{ Siri Kini } \\
\hline \multirow{7}{*}{$\begin{array}{l}00+0.000 \mathrm{~L}- \\
00+1.000 \mathrm{~L}\end{array}$} & Plepasan Butir & $\mathrm{M}$ & 3,7429 & 12 \\
\hline & Pelepasun Butir & $\mathrm{L}$ & 1,2429 & 1 \\
\hline & Blooding & $\mathrm{M}$ & 0,1429 & 0 \\
\hline & Doformasai & $\mathrm{M}$ & 0,1429 & 11 \\
\hline & Lubang & $\mathbf{M}$ & 0,2557 & 10 \\
\hline & Lubang & $\mathrm{L}$ & 0,2714 & 9 \\
\hline & Retal Buryz & $\mathrm{L}$ & 0,3429 & 5 \\
\hline
\end{tabular}

Berdasarkan penelitian yang telah dilakukan di sepanjang jalan Srijaya Raya Palembang sepanjang $1 \mathrm{KM}$, maka didapatkan total Deduct Value adalah sebesar 57 dengan detail seperti pada tabel di atas.

\section{d. Mencari Corrected Deduct Value (CDV).}

Nilai Corrected Deduct Value (CDV) diperoleh dengan memasukan nilai DV ke grafik CDV dengan cara menarik garis vertikal pada nilai TDV sampai memotong garis q kemudian ditarik garis horizontal. Nilai q merupakan jumlah masukan dengan DV yang mempunyai nilai lebih besar dari 2.

Berdasarkan Gambar 1 Grafik Hubungan CDV dan TDV untuk perkerasan lentur, maka didapatkan nilai 39 .

\section{e. Nilai kondisi perkerasan (PCI).}

Nilai kondisi perkerasan dengan mengurangi 100 dengan nilai CDV yang diperoleh, maka nilai PCI untuk tiap unit dapat diketahui dengan menggunakan rumus.2.4

$$
\begin{gathered}
\text { PCI }(s)=100-\mathrm{CDV} \\
\mathrm{PCI}=100-39 \\
\text { PCI }=61
\end{gathered}
$$

\section{f. Klasifikasi Perkerasan}

Nilai PCI memiliki rentang $0-100$ dengan kriteria sempurna (Excellent), sangat baik (very good), baik (good), sedang (fair), jelek (poor), sangat jelek (very poor), dan gagal (failed). Berdasarkan metode Pavement Condition Index $(P C I)$, penilaian kondisi kerusakan yang disarankan FAA (1982) dan Shahin (1994).

Tabel 6. Nilai PCI dan kondisi klasifikasi kualitas perkerasan jalan (FAA, 1982)

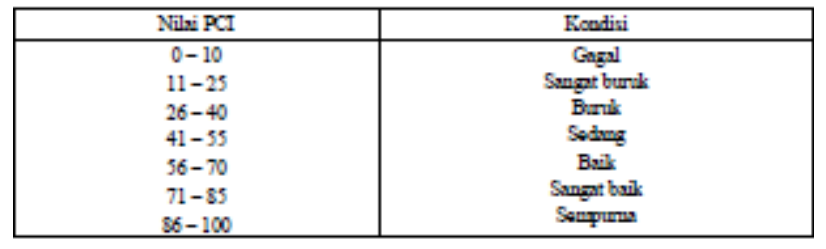


Berdasarkan tabel 6 di atas, maka klasifikasi jalan Srijaya Raya Palembang adalah baik

\section{Penanganan Perbaikan}

Setelah dilaksanakan perhitungan indeks kerusakannya, kemudian dapat ditarik kesimpulan bahwa jalan Srijaya Raya memang membutuhkan penanganan untuk perbaikan guna kelancaran dalam berkendara.

Sebelum dibuat rencana biaya penanganannya, maka sebelumnya dibuat gambar situasi jalan raya atau street map dari hasil pengurukan di lapangan.

Dapat dilihat pada gambar di bawah adalah gambar street map yang telah dilakukan perhitungan dan penilaian jalan, serta pada gambar dibagian bawah merupakan rencana perbaikan nya.

Sedangkan untuk masing - masing penanganannya sendiri juga disesuaikan dengan jenis dan tipe kerusakannya masing masing. Secara setail penangannya dapat dilihat pada tabel 6 .

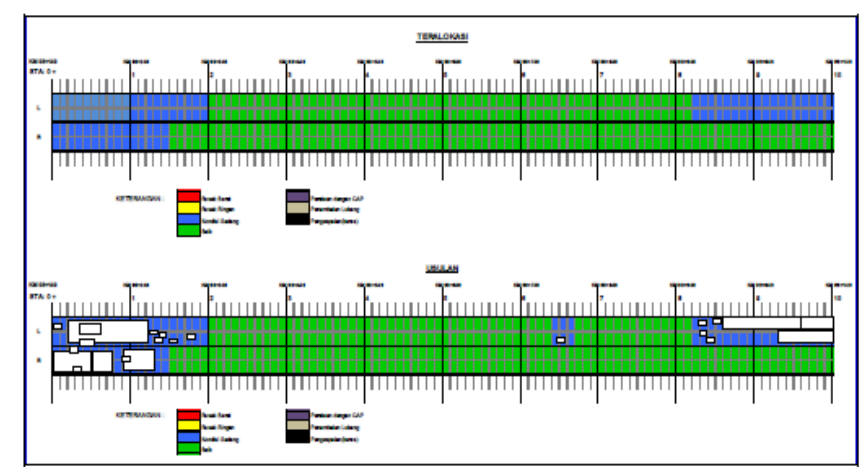

Gambar 6. Hasil Perhitungan dan rencana perbaikan seluruh ruas Jalan sepanjang $1 \mathrm{KM}$

Tabel 7. Penanganan Perbaikan

\begin{tabular}{|c|c|}
\hline Jenis Kerusalzan & Tindakan perbailkan \\
\hline Pengelupasan & $\begin{array}{l}\text { Pengelupasan merupalsan kerusalsan yang paling dominan } \\
\text { dan perbaikannya dengan metode } \mathrm{P} 2 \text { dengan memberikan } \\
\text { lapisan tambah di atas lapisan yang mengalami } \\
\text { pengelupasan (overlay). }\end{array}$ \\
\hline $\begin{array}{l}\text { Deformasi } \\
\text { Amblas dan } \\
\text { bleeding atau } \\
\text { kegemukan }\end{array}$ & $\begin{array}{l}\text { Tindakan perbaikan dapat dilakukan dengan metode P5 } \\
\text { yaitu dengan mengisi bagian jalan yang amblas dengan } \\
\text { agregat, kemudian dengan pemadatan dengan campuran } \\
\text { aspal. Untuk amblas } \leq 5 \mathrm{~cm} \text {, bagian yang rendah disi } \\
\text { dengan bahan sesuai seperti lapen, lataston, laston. Unruk } \\
\text { amblas yang } \geq 5 \mathrm{~cm} \text {, bagian yang amblas dibongkar dan } \\
\text { dilapisi kembali dengan lapis yang sesuai. }\end{array}$ \\
\hline Pelepasan butir & $\begin{array}{l}\text { Tindakan perbalkan dapat dilakukan dengan metode } \mathrm{P} 2 \text {, } \\
\text { memberikan lapisan tambahan di atas lapisan yang } \\
\text { mengalami pelepasan butir setelah lapisan tersebut } \\
\text { dibersihkan, dan dikeringkan. }\end{array}$ \\
\hline Lubang & $\begin{array}{l}\text { Penanganan dengan metode P5 dengan melakukan } \\
\text { penambalan lubang (patching) dan penambahan lapisan } \\
\text { perkerasan (overlay). }\end{array}$ \\
\hline
\end{tabular}

Dari tabel di atas dapat dilihat ada 2 kode yang digunakan, yaitu P2 dan P5. Untuk kode P2 digunakan hanya untuk memberikan lapisan tambahan berupa aspal. Namun lebar yang diaspal haruslah menyeluruh. Untuk jalan Srijaya Raya sendiri maka sekali melakukan pengaspalan haruslah diukur lebar jalan $(7 \mathrm{~m}$ ) sepanjang $150 \mathrm{~m}$.

Adapun urutan kerja kegiatan pengaspalan yang biasa dilakukan adalah sebagai berikut :

- Mobilisasi peralatan, pekerja, dan material ke lapangan

- Tempatkan rambu pengaman dan alihkan lalu lintas

- Siapkan peralatan

- Bersihkan daerah tersebut dengan Air Compressor

- Tandai daerah yang akan diperbaiki

- Semprotkan aspal emulsi $1.5 \mathrm{liter} / \mathrm{m}^{2}$ di daerah yang akan diperbaiki

- Untuk "cut back" 1 liter/m2 (proporsi percobaan di lapangan)

- Dengan aspal emulsi, tunggu sampai aspal mulai pecah sebelum langkah 3 berikut (aspal emulsi berubah warna dari coklat menjadi hitam bila retak

- Taburkan pasir kasar atau agregat $5 \mathrm{~mm}$ di daerah yg diperbaiki

- Padatkan pasir atau agregat dengan Baby Roller (minimum 3 lintasan)

- Angkat peralatan dengan menggunakan Flat Bed Truck

- Demobilisasi

Adapun harga satuan untuk kegiatan pengaspalan adalah Rp. $17.056 / \mathrm{m} 2$, dengan detail komponen dapat dilihat pada Tabel 8 di bawah ini. 
Tabel 8. Harga Satuan Kegiatan Pengaspalan (P2)

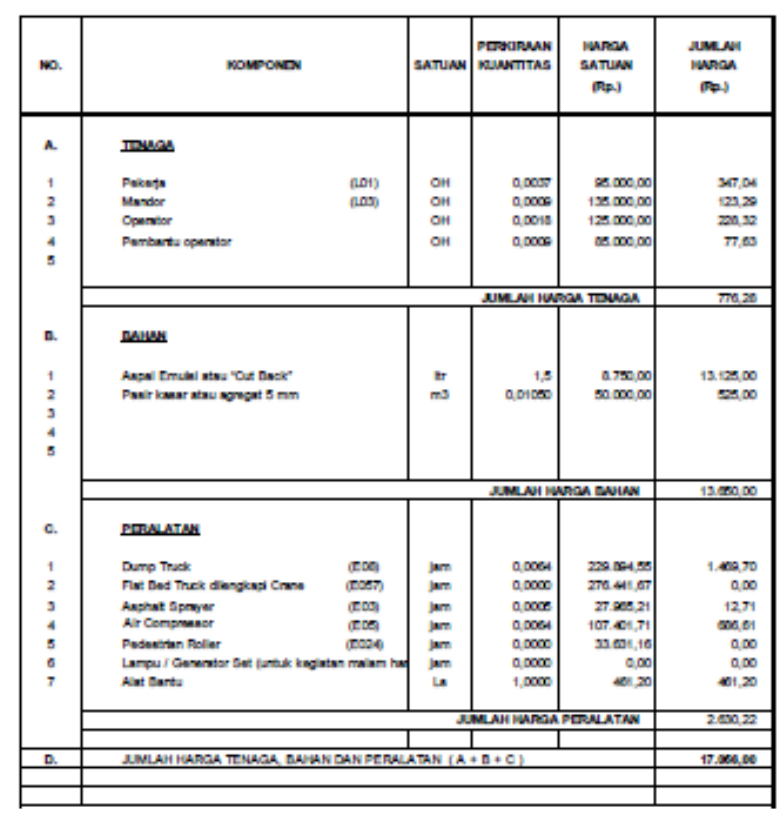

Sedangkan untuk kode P5 adalah kegiatan penambalan jalan atau patching dilakukan dengan pengukuran per satuan kerusakan dalam satuan m2. Lebar dan panjang kerusakan diukur dan dihitung luasannya. Penambalan jalan dilakukan untuk memperbaiki jalan yang berlubang.

Adapun urutan kerja pekerjaan patching ini adalah sebagai berikut :

- Mobilisasi peralatan, pekerja, serta material ke lapangan,

- Tempatkan rambu pengaman dan alihkan lalu lintas.

- Bersihkan daerah perbaikan memakai Air Compressor.

- Penggalian lubang memakai linggis ( jack Hammer) yang di pasang pada Air Compresor sampai kedalaman perkerasan jalan $200 \mathrm{~mm}$

- Setelah lubang diratakan lalu dipadatkan memakai Vib. Hammer

- Lubang diisi Aggregat A maksimum ketebalam $10 \mathrm{~mm}$ kemudian dipadatkan lalu ditambahkan lagi lapis Aggregat A samapai $40 \mathrm{~mm}$ dibawah permukaan dipadatkan kembali memakai vibrating Tamper atau Hammer

- Laburkan prime coating $0.8 \mathrm{ltr} / \mathrm{m}^{2}$ memakai aspal emulsi

- Siapkan campuran dingin memakai concrete mixer
- Taburkan campuran aspal dingin diatas lubang sampai rata. Padatkan dengan pemadat Baby Roller (min 5 lintasan)

- Bersihkan area pekerjaan dan periksa kerataan permukaan

- Demobilisasi Peralatan

Adapun harga satuan untuk kegiatan pengaspalan adalah Rp. $285.826 \quad / \mathrm{m} 2$, dengan detail komponen dapat dilihat pada Tabel 8 di bawah ini.

Tabel 9. Harga Satuan Penambalan Lubang yang mengalami Deformasi (P5)

\begin{tabular}{|c|c|c|c|c|c|}
\hline no. & KOMPONEN & GAT & $\begin{array}{l}\text { PESSIRAaN } \\
\text { KUaATITAG }\end{array}$ & $\begin{array}{l}\text { ruson } \\
\text { catuan } \\
(\text { Inp.) }\end{array}$ & 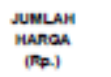 \\
\hline a & IFNAQA KEn.A & & & & \\
\hline 1 & Pelowis & $\mathrm{OH}$ & 0,0520 & $88.000,00$ & $3.780,78$ \\
\hline 2 & Merdar & $\mathrm{OH}$ & 0,0067 & $135,000,00$ & abs, 02 \\
\hline \multirow{3}{*}{$\begin{array}{l}3 \\
5\end{array}$} & operstx & $\mathrm{OH}$ & 0,0007 & 125000,00 & asi,31 \\
\hline & Pembintu speress & $\mathrm{OH}$ & 0,0007 & $88,000,00$ & $\operatorname{ses}, 28$ \\
\hline & \multicolumn{4}{|c|}{ JUMLAH MAROA TEMAOA } & $8.080,22$ \\
\hline a & Danavenstranial & & & & \\
\hline 1 & Aroge Kles $-\mathrm{A}$ & $m$ & 0,2000 & 450.000 .00 & $91.900,00$ \\
\hline 2 & 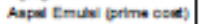 & tr & 0,8000 & $8.750,00$ & 7000,00 \\
\hline 3 & Aapa Pen Cost: & tr & 5,0334 & $7.741,84$ & 45. 161,01 \\
\hline 4 & Agrope kan: & $m$ & 0,0250 & $450.000 .0 \mathrm{~d}$ & $12.55 s, 00$ \\
\hline$s$ & Aprogethesa & $m 3$ & 0,0500 & $450,000,00$ & 13968,00 \\
\hline \multirow[t]{2}{*}{$s$} & Konu Dakis & $\infty$ & 0,1400 & 1500000,00 & $14,060,00$ \\
\hline & \multicolumn{4}{|c|}{ JUMLAH MA MPA DAILYY } & $104,421,61$ \\
\hline a. & PRQALATBY & & & & \\
\hline 1. & Dump Truck (coos) & ment & 0,1800 & $202004=8$ & $4.115,29$ \\
\hline 2 & Aar Compren (tros) & en & 0,0400 & $107.401,71$ & 4982,25 \\
\hline 3 & Jeck Hemm (tose) & ) ent & 0,3303 & 102001,80 & 34220,00 \\
\hline 4 & Vteneing Pa (Et4) & en & 0,0000 & $11.205,83$ & 0,00 \\
\hline s & 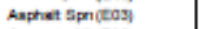 & 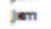 & 0,0002 & $27.065,24$ & Q.TA \\
\hline$s$ & Concrest Mn (toof) & m & 0,0000 & $30.000,00$ & 0,00 \\
\hline 7 & Detby Molle: (DOA) & 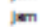 & 0,0050 & $33.631,16$ & 108,63 \\
\hline 8 & net Ded Tru (test) & m & 0,0158 & $430.341,80$ & 6.917, 54 \\
\hline 8 & Lampu / Genereor Bat (un & 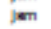 & 0,0000 & 0,00 & $0, \infty$ \\
\hline \multirow[t]{3}{*}{ to } & 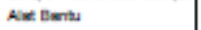 & Ls & 1,0000 & 3200,31 & 3980,31 \\
\hline & & & \multirow{2}{*}{\multicolumn{2}{|c|}{ 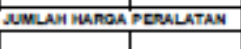 }} & DS 1320,03 \\
\hline & & & & & \\
\hline a. & JUMLAH HANGCA TENAGA & $\operatorname{sen} / 2$ & DAN PEDALATA & $(A+B+C)$ & ses.aza,, 0 \\
\hline & & & & & \\
\hline
\end{tabular}

Berdasarkan hasil survey dan perhitungan luasan didapatkan data sesuai dengan tabel di atas, dan kolaborasi dengan tabel 8 dan 9, didapatkan total rencana biaya perbaikan sesuai dengan tabel 10 di bawah ini.

Tabel 10. Total Rencana Biaya Perbaikan

\begin{tabular}{|c|c|c|c|c|c|}
\hline STA & Jenis Kerwalan & Peuanganan & Lmasan (min) & $\begin{array}{c}\text { Herga Saruan } \\
\left(\mathrm{m}^{2}\right)\end{array}$ & Total Biays \\
\hline \multirow{2}{*}{$\begin{array}{l}00+000 R- \\
00+095 \mathbb{R}\end{array}$} & Polopasan Butir & P2 ( Peoparpolman) & $7 \mathrm{mx} 150 \mathrm{~m}$ & $17.056,00$ & 17.908 .800 \\
\hline & & & & & \\
\hline $00+142 \mathrm{~L}$ & Pelopasen Butir & P2 (Peomandm) & $7 \mathrm{mx} 130 \mathrm{~m}$ & $17.056,00$ & 17.908 .800 \\
\hline $00+0+2 \mathrm{~L}$ & Lubager & P5 (Pramboling) & 41 & $285.828,00$ & 11.718948 \\
\hline $00+145 \mathrm{~L}$ & Devommai & P5 (Penembalinn) & 10 & $285.828,00$ & 2.858 .280 \\
\hline $00+658 \mathrm{~L}$ & Polopgsm Butir & P5 (Pvarmbalan) & $7 \mathrm{mx} 150 \mathrm{~m}$ & $17,056,00$ & 17.908 .800 \\
\hline $00+847 \mathrm{~L}$ & Realk Burya & P2 (Peoparpalm) & $7 \operatorname{mx} 150 \mathrm{~m}$ & $17.056,00$ & 17.908 .800 \\
\hline & & & & TOTAL & 86.212 .428 \\
\hline
\end{tabular}


Berdasarkan hasil survey, penelitian, dan perhitungan, maka didapatkan total Rencana Panggunaan Biaya untuk perbaikan jalan pada lokasi KM 8+145 - KM 9+145 adalah Rp.86.212.428,- atau dibulatkan Rp. 86.213.000,--
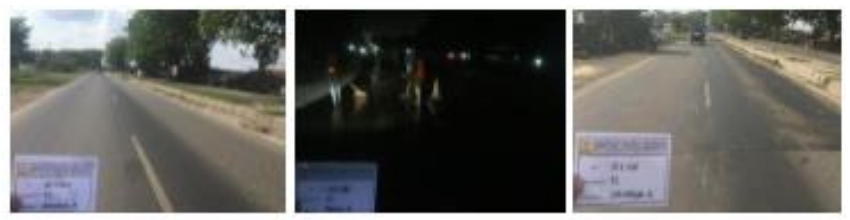

Gambar 7. Kegiatan Perbaikan Pengaspalan

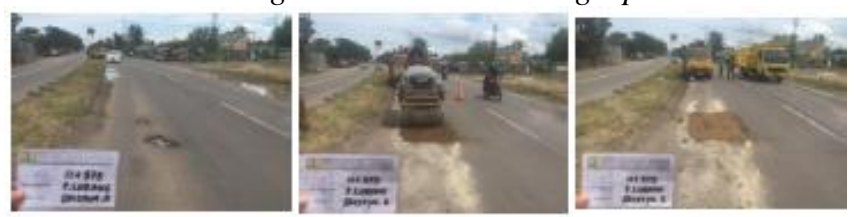

Gambar 8. Kegiatan Perbaikan Penambalan Lubang

\section{Kesimpulan}

Dari hasil observasi lapangan dan analisa kondisi serta perhitungan, maka didapatkan kesimpulan sebagai berikut :

1. Terdapat 4 jenis kerusakan yang terjadi pada ruas jalan Srijaya Raya KM 8+149 sampai dengan KM 9+149, yaitu pelepasan butir, devormasi / penurunan, bleeding atau kegemukan, lubang, dan retak buaya.

2. Secara umum nilai PCI untuk jalan Srijaya Raya pada KM 8+149 sampai dengan KM 9+149 adalah 61, yang artinya kondisi jalan dalam keadaan baik

3. Total biaya pemeliharaan terhadap kerusakan yang diderita oleh jalan Srijaya Raya pada KM 8+149 sampai dengan KM 9+149 adalah Rp. 86.212.428,- atau dibulatkan Rp. 86.213.000,-.

\section{DAFTAR PUSTAKA}

[1]. 1980. Undang-Undang Nomor 13 Tahun 1980 Tentang Jalan.

[2]. ASTM D6433. 2007. Standard Practice for Roads and Parking Lots Pavement Condition Index Surveys. 48 pp.
[3]. Bolla, Margareth Evelyn. 2010. Perbandingan Metode Bina Marga dan Metode PCI (Pavement Condition Index) Dalam Penilaian Kondisi Perkerasan Jalan (Studi Kasus Ruas Jalan Kaliurang, Kota Malang). Fakultas Sains dan Teknik, Universitas Nusa Cendana. Nusa Tenggara Timur.

[4]. Irzami. 2010. Penilaian Kondisi Perkerasan dengan Menggunakan Metode Indeks Kondisi Perkerasan Pada Ruas Jalan Simpang Kulim - Simpang Batang. (Tesis). Magister Teknik Sipil, Universitas Islam Riau. Pekanbaru.

[5]. Kahiri, Amin. 2012. Evaluasi Jenis dan Tingkat Kerusakan dengan Menggunakan Metode Pavement Conditon Index (PCI) Studi Kasus Jalan Soekarno-Hatta, Dumai 05+00010+000. Fakultas Teknik, Politeknik Negeri Bengkalis. Dumai.

[6]. Putri, Selvia Eka. 2014. Pengaruh Pelebaran Ruas Jalan Terhadap Peningkatan Kinerja Lalu Lintas (Studi Kasus Jalan Soekarno-Hatta/Bypass Bandar Lampung). Fakultas Teknik, Universitas Lampung. Bandar Lampung.

[7]. Septiawan, Catur Budi. 2013. Laporan Kerja Praktik Proyek Pelaksanaan Preservasi dan Peningkatan Kapasitas Jalan dan Jembatan Nasional Sp. Tanjung Karang-Batas Kota SukamajuKalianda dan Sekitarnya, Paket : Bandar Lampung-Bypass A (SoekarnoHatta). Fakultas Teknik, Universitas Lampung. Bandar Lampung.

[8]. Shahin, M.Y., Walther, J.A. 1994. Pavement Maintenance Management for Roads and Streets Using The PAVER System. US Army Corps of Engineer. New York. 282 pp.

[9]. Sukirman, Silvia. 1999. Perkerasan Lentur Jalan Raya. Nova. Bandung. 243 hlm.

[10]. Suswandi, Agus., Sartono, W., Christiady, H. 2008. Evaluasi Tingkat Kerusakan Jalan Dengan Metode Pavement Condition Index (PCI) Untuk Menunjang Pengambilan Keputusan (Studi Kasus Jalan Lingkar Selatan, Yogyakarta). Forum Teknik Sipil No. XVIII. Yogyakarta. 